\title{
Efecto del tratamiento térmico sobre la composición química y minerales en semillas de lupinos silvestres
}

\author{
Effect of thermal treatment on the \\ chemical composition and \\ minerals of wild lupin seeds
}

Elia Herminia Valdés-Miramontes (1)

Antonio López-Espinoza (1)

Ramón Rodríguez-Macías (2)

Eduardo Salcedo-Pérez (3)

Mario Alberto Ruiz-López (2)

\begin{abstract}
Wild lupine consumption has restrictions due to the presence of alkaloids; however, these components can be reduced with a suitable thermal treatment. The aim of this research was to determine the thermal effect on chemical composition and minerals of wild lupine. Lupinus mexicanus had a reduction in protein and fat contents of 34.76 to 33.11 and 6.10 to $5.41 \mathrm{~g} / 100 \mathrm{~g}$ of sample respectively, and an increase in ash and dietary fiber of 3.84 to $4.53 \mathrm{~g} / 100 \mathrm{~g}$ and 20.9 to $28.48 \mathrm{~g} / 100 \mathrm{~g}$ respectively. L. mexicanus raw seeds revealed the highest Ca content (3,252 mg/ $\mathrm{kg})$, L. elegans was the highest in Mg with 2,656 mg/kg. Highest Fe content was found in Lupinus rotundiflorus $(82.8 \mathrm{mg} / \mathrm{kg})$, and Lupinus exaltatus in Cu $(184.4 \mathrm{mg} / \mathrm{kg})$. All species showed similar $\mathrm{Zn}$ content of $73.3 \mathrm{mg} / \mathrm{kg}$ (Lupinus montanus) to $89.6 \mathrm{mg} / \mathrm{kg}$ ( $\mathrm{L}$. exaltatus). In all species the $\mathrm{Cu}$ content decreased, mainly in Lupinus elegans with a loss of $76,71 \%$
\end{abstract}

Key words: Lupinus, legumes, minerals, thermal effect, dietary fiber.

\begin{abstract}
(1) Centro de Investigaciones en Comportamiento Alimentario y Nutrición (CICAN) Centro Universitario del Sur, Universidad de Guadalajara. México (2) Departamento de Botánica y Zoología. Centro Universitario de Ciencias Biológicas y Agropecuarias Universidad de Guadalajara. México (3) Departamento de Madera Celulosa y Papel. Centro Universitario de Ciencias Exactas e Ingenierías Universidad de Guadalajara, México. México

Dirigir la correspondencia a:

Mario Alberto Ruiz López Departamento de Botánica y Zoología Centro Universitario de Ciencias Biológicas y Agropecuarias Universidad de Guadalajara México

Km 15.5. Carretera Guadalajara-Nogales, Las Agujas, Zapopan, Jalisco, C.P. 45110, México Fax: +523337771150 E-mail:mruiz@cucba.udg.mx).
\end{abstract}

Este trabajo fue recibido el 21 de Octubre de 2014 y aceptado para ser publicado el 10 de Abril de 2015.

\section{INTRODUCTION}

Legumes are the most important vegetable source of protein and represent approximately $20 \%$ of human diets. Throughout history they have been a very important food resource, also they are an inexpensive source of dietary fiber (DF) and minerals [1].

The legume consumption presents inconveniences because of presence of antinutritional and toxic factors, nevertheless these components can be eliminated or decreased with an adequate thermal treatment $[2,3]$, but this treatment also affects the nutrients so it is necessary to know its effect on them.

Dietary fiber (DF) is one of the most important nutritional ingredients used in functional foods and in 1980's decade it was one of the first ingredients associated with health [4], given that epidemiologic studies have suggested there is a relation between a decrease in DF consumption and an increase in gastrointestinal illnesses [5], hypercholesterolemia and colorectal cancer [6]. The DF is non-digestible carbohydrates and lignin which are inherent on the plant's cell wall and for their non-digestible characteristics some DF are considered prebiotic, a growth stimulant of beneficial intestinal bacteria, which improves the health of host [7].

Even though legumes are an important source of DF there are few studies on their modification after being treated thermally $[2,8]$.

Lupin kernel flour (LKF) is a novel food ingredient that is high in protein and fiber, and to show that partial substitution of refined wheat-derived carbohydrate in bread with protein and fibre from LKF can reduce appetite and energy intake acutely. In addition, several studies have suggested that lupin may reduce cholesterol concentrations and benefit glucose and insulin metabolism [9].

In this respect, species of the Lupinus genus (legumes) 
are currently receiving great interest as a promising source of nutritional ingredients, and in countries such as Australia, Poland, Germany, Chile, and Ecuador, different species are being cultivated such as L. albus, L. angustifolius, L. luteus and L. mutabilis [10] and incorporating their seeds into different foods for human and animal consumption [11].

Lupin cultivation represents $10 \%$ of the world's grain production, currently the largest production is in Australia $(779,242$ tons per year on average in the last five years) where in 2009, the FAOSTAT reported a cultivated surface area of $662,712 \mathrm{Ha}$ of this legume, which represents $85 \%$ of the lupine cultivation in the world.

In the other hand, in Mexico there are close to 100 native species of Lupinus widely distributed, representing a great potential due to high protein content which varies from $30-$ $40 \mathrm{~g} / 100 \mathrm{~g}$ in dry basis and of oil of 8-12g/100 $\mathrm{g}$ depending on the species, variety, and environmental conditions [12, 13]. However, their use is limited by quinolizidine alkaloid content which makes the seed bitter and toxic, nevertheless these compounds may be removed up to a $95 \%$ through an extraction with boiling water $[2,14]$.

Due to the aforementioned, this investigation analyzed the thermal effect (cooking) on chemical composition, total dietary fiber and minerals content in seeds of five species of wild Lupinus from Jalisco state, Mexico.

\section{MATERIALS AND METHOD}

Lupin samples: Mature seeds from L. rotundiflorus, L exaltatus, L. elegans, L. montanus and L. mexicanus were collected in various regions in Jalisco state of Mexico during the spring-fall seasons of 2010. All species were botanically classified and deposited in Herbarium of Botany Institute of the University of Guadalajara (IBUG) Mexico.

Chemical analysis: From the collected seeds, 500g of each species were boiled in bidistilled water $(1: 5 \mathrm{w} / \mathrm{v})$ at atmospheric pressure for 3 hours, with water replacements, the raw and boiled seeds were dehydrated at $55^{\circ} \mathrm{C}$ for 48 hours on a forced air furnace and ground to a size of $0,5 \mathrm{~mm}$ of diameter to carry out a chemical analysis in triplicate for each samples, in according to standard methods of AOAC [15] fat (930.09), ash (940.26), protein (950.48), and dietary fiber were analyzed by means of the enzymatic-gravimetric method.

Mineral analysis: The content of minerals ( $\mathrm{Ca}, \mathrm{Mg}, \mathrm{Fe}$, $\mathrm{Zn}, \mathrm{Cu}$ ) was carried out in triplicate by means of flame atomic absorption (GBC-AVANTA), the ashes from the samples were diluted in an acid solution and filtered (AOAC [15] method 968.08). Phosphorus was analyzed through the colorimetric method using ammonium molybdenum (AOAC [15] method 965.17).

Statistical analysis: The data was analyzed using t test, with a confidence interval of $95 \%$ using the statistical software JMP®.

\section{RESULTS AND DISCUSSION}

The results on the chemical composition and the cooking effect on the five Lupinus species analyzed are shown in table 1.

Protein value in raw seeds varied depending of species, from $34.76 \mathrm{~g} / 100 \mathrm{~g}$ of sample in L. mexicanus to $43.93 \mathrm{~g} / 100$ $\mathrm{g}$ in L. exaltatus, the value in this species was greater to that reported early in wild lupins $[13,14,16]$. Also, in L. montanus a higher protein content was found $(42.42 \mathrm{~g} / 100 \mathrm{~g})$ than those observed by Guemes-Vera et al., [17] of 35.27g/100 g and Lagunes-Espinoza et al., [16] of 38.7g/100 $\mathrm{g}$ in this same specie, whereas the values in L. elegans $(43.66 \mathrm{~g} / 100 \mathrm{~g})$ and $\mathrm{L}$. rotundiflorus $(41.96 \mathrm{~g} / 100 \mathrm{~g})$ were slightly lower than those reported by Ruiz and Sotelo [14] of 45.41 and 42.82 respectively. These divergences in chemical composition of the same species is due, according to Wolko et al. [18], to differences in the locality, time of the year or climate conditions of the collected seeds.

Overall, protein content in researched lupines was greater than those found in other Mexico wild species as L. reflexus (37.31g/100 g ), L. splendens (37.2), L. campestris (39.7) and L. barkeri $(37.07 \mathrm{~g} / 100 \mathrm{~g})[2,14,17]$ and from Spain, such

\section{TABLE 1}

Chemical composition of raw and cooked L.exaltatus, L.elegans, L.mexicanus, L. montanus and $L$. rotundiflorus seeds $\left(\mathrm{g} / 100 \mathrm{~g}\right.$ in dry basis) ${ }^{\mathrm{a}}$

\begin{tabular}{|c|c|c|c|c|c|}
\hline SPECIES & & $\begin{array}{l}\text { PROTEIN } \\
(\mathrm{N} \times 6.25)\end{array}$ & FAT & ASH & DF \\
\hline \multirow[t]{2}{*}{ L. exaltatus } & Raw & $43,93 \pm 0.4$ & $8,76 \pm 0.2^{*}$ & $3,47 \pm 0.1^{*}$ & $17,72 \pm 0.1^{*}$ \\
\hline & Cooked & $43,46 \pm 0.5$ & $8,21 \pm 0.1$ & $2,88 \pm 0.2$ & $33,06 \pm 0.1$ \\
\hline \multirow[t]{2}{*}{ L. elegans } & Raw & $43,66 \pm 0.2$ & $7,31 \pm 0.1^{*}$ & $4,27 \pm 0.0$ & $21,07 \pm 0.0$ \\
\hline & Cooked & $43,33 \pm 0.2$ & $6,42 \pm 0.1$ & $4,05 \pm 0.1$ & $21,45 \pm 0.1$ \\
\hline \multirow[t]{2}{*}{ L. mexicanus } & Raw & $34,76 \pm 0.3^{*}$ & $6,10 \pm 0.2^{*}$ & $3,84 \pm 0.5^{*}$ & $20,90 \pm 0.5^{*}$ \\
\hline & Cooked & $33,11 \pm 0.9$ & $5,41 \pm 0.1$ & $4,53 \pm 0.0$ & $28,48 \pm 0.0$ \\
\hline \multirow[t]{2}{*}{ L. montanus } & Raw & $42,42 \pm 0.3$ & $7,57 \pm 0.2$ & $3,64 \pm 0.1^{*}$ & $24,63 \pm 0.1^{*}$ \\
\hline & Cooked & $42,20 \pm 0.1$ & $7,32 \pm 0.1$ & $3,25 \pm 1.1$ & $26,10 \pm 0.1$ \\
\hline \multirow[t]{2}{*}{ L. rotundiflorus } & Raw & $41,96 \pm 0.1^{*}$ & $6,45 \pm 0.1$ & $3,10 \pm 0.1$ & $27,93 \pm 0.1$ \\
\hline & Cooked & $37,52 \pm 0.3$ & $6,26 \pm 0.1$ & $3,04 \pm 0.0$ & $27,41 \pm 0.0$ \\
\hline
\end{tabular}


as L. gredensis (23.8g/100 g ), L. mariaejosephi (32.9) and L. luteus $(33.6 \mathrm{~g} / 100 \mathrm{~g})[19,20]$ and similar to the domesticated varieties of L. albus, L. luteus and L. angustifolius (30 to 40 $\mathrm{g} / 100 \mathrm{~g}$ ) [21].

All of the seeds had a slight reduction in protein due to the thermal treatment but not significant, with exception of L. rotundiflorus with a significant reduction $(p<0.05)$ of 41.96 to $37.52 \mathrm{~g} / 100 \mathrm{~g}$. These results do not coincide with those reported by Jiménez et al., [2] whom observed an increase of this nutrient in Lupinus campestris seeds of $39.7 \mathrm{~g} / 100 \mathrm{~g}$ to $49.7 \mathrm{~g} / 100 \mathrm{~g}$ after being submitted to a six hour thermal treatment. This difference may be possible due to different cooking times. However, our results were similar to those reported in other legumes where cooking of the Canavalia cathartica seeds did not show any significant statistical difference in relation to the raw seeds [22]. Additionally, other authors observed a $50 \%$ or more reduction in the protein content in traditional legume consumption, such as Phaseolus vulgaris, Cicer arientinum, Pisum sativum and Lens culinaris with less or equal cooking times [23], this is because these legumes have a softer coat more than the lupins, which made it easier to solubilize the proteins while cooking.

The fat value was $6.1 \mathrm{~g} / 100 \mathrm{~g}$ in $\mathrm{L}$. mexicanus at 8.76 $\mathrm{g} / 100 \mathrm{~g}$ in L. exaltatus in raw seeds it was similar to what was found by Ruiz and Sotelo [14] whom reported percentages in wild lupines of 5.79 to 8.89 and less to what was reported in L. campestris $(10.8 \mathrm{~g} / 100 \mathrm{~g})$ by Jiménez et al., [2]. Cooking had an effect on fat to reducing the content in all the analyzed seeds, this does not correspond with what Jiménez et al., [2] who reported an increase in fat was assessed in the L. campestris of $10.8 \mathrm{~g} / 100 \mathrm{~g}$ to $13.2 \mathrm{~g} / 100 \mathrm{~g}$ with an aqueous thermal treatment. On their behalf, Alajaji and El-Adawy [24] reported that when boiling in water, fat was reduced in chickpea seeds (6.48 to $6.22 \mathrm{~g} / 100 \mathrm{~g}$ ).

Ash content of $3.10 \mathrm{~g} / 100 \mathrm{~g}$ in L. rotundiflorus to 4.27 $\mathrm{g} / 100 \mathrm{~g}$ in L. elegans was within the reported range by other authors. Ashes presented a statistically significant reduction $(p<0.05)$ by the thermal treatment except for L. elegans and an increase in L. mexicanus of 3.84 to $4.53 \mathrm{~g} / 100 \mathrm{~g}$.

The loss of total minerals varies whit treatment in regards to the element and species. The contact with the water, especially during cooking and blanching, causes considerable mineral loss depending on the solubility of the mineral.

Meanwhile, dietary fiber (DF) in raw seeds showed a greater variation with values of $17.72 \mathrm{~g} / 100 \mathrm{~g}$ (L. exaltatus) to $27.93 \mathrm{~g} / 100 \mathrm{~g}$ (L. rotundiflorus). There are no reports on the DF in wild lupines, only in domestic species, such as L. albus with 35.3 to $50.4 \mathrm{~g} / 100 \mathrm{~g}$ [25] and L. angustifolius with $31.6 \mathrm{~g} / 100 \mathrm{~g}[26]$, these values are greater than those found in the analyzed species in this investigation. The values of wild lupin studied are highest to others legumes reported as soybean, black soybean, azuki bean and mung bean [27].

An increase in DF content was observed by the thermal treatment in all of the analyzed species and statistically significant $(p<0.05)$ in L. exaltatus, L. mexicanus and L. montanus of 17.72 to $33.06 \mathrm{~g} / 100 \mathrm{~g}, 20.90$ to $28.48 \mathrm{~g} / 100 \mathrm{~g}$ and 24.63 to $26.1 \mathrm{~g} / 100 \mathrm{~g}$, respectively, similar data was found by Alajaji and El-Adawy [24] where they report a statistically significant $(p<0.05)$ increase in chickpea fiber content when subjected to cooking in water. Lintas et al. [28] recount that thermal treatment may have different effects in the content of DF in food, since cooking promotes the breakdown of components of the DF with proteins and lipids creating essential qualitative and/or quantitative changes.

There is a contradiction between authors when reporting a rise or reduction in the DF as a consequence of cooking. These differences are due to the soluble or insoluble components of the DF which react during the soaking and cooking of the seeds [29].

Minerals concentration in raw seeds varied among species (table 2), in L. mexicanus have greatest value of calcium (3252 $\mathrm{mg} / \mathrm{kg}$ ) followed by L. montanus ( $2074 \mathrm{mg} / \mathrm{kg}$ ) and L. exaltatus $(2052 \mathrm{mg} / \mathrm{kg})$. These values are higher to the ones reported in L. montanus $(800 \mathrm{mg} / \mathrm{kg}$ ) and L. exaltatus $(1600 \mathrm{mg} / \mathrm{kg})$ from Puebla, Mexico [30]. As well L. angustifolius (2200 mg/ $\mathrm{kg})$, L. albus (2000 mg/kg), L. mutabilis $(1800 \mathrm{mg} / \mathrm{kg})$ and L.

\section{TABLE 2}

Mineral content in raw and cooked L.exaltatus, L.elegans, L.mexicanus, L. montanus and $L$. rotundiflorus seeds $\left(\mathrm{mg} / \mathrm{kg}\right.$ in dry basis) ${ }^{\mathrm{a}}$

\begin{tabular}{|c|c|c|c|c|c|c|c|}
\hline SPECIES & & $\mathrm{Ca}$ & $\mathrm{P}$ & $M g$ & $\mathrm{Fe}$ & $\mathrm{Zn}$ & $\mathrm{Cu}$ \\
\hline \multirow[t]{2}{*}{ L. exaltatus } & Raw & $2052 \pm 305$ & $584 \pm 321$ & $2330 \pm 212^{*}$ & $61,8 \pm 7,5$ & $89,6 \pm 1,6^{*}$ & $184 \pm 3,1^{*}$ \\
\hline & Cooked & $1700 \pm 404$ & $458 \pm 43,6$ & $1690 \pm 113$ & $49,3 \pm 10,0$ & $76,5 \pm 5,5$ & $68,5 \pm 14,1$ \\
\hline \multirow[t]{2}{*}{ L. elegans } & Raw & $1777 \pm 702 *$ & $6441 \pm 702^{*}$ & $2656 \pm 423$ & $70,9 \pm 11,3^{*}$ & $73,6 \pm 4,4$ & $64,8 \pm 4,2^{*}$ \\
\hline & Cooked & $680 \pm 200$ & $2876 \pm 435$ & $2488 \pm 121$ & $52,4 \pm 5,6$ & $74,8 \pm 4,4$ & $15,1 \pm 1,2$ \\
\hline \multirow[t]{2}{*}{ L. mexicanus } & Raw & $3252 \pm 378$ & $5865 \pm 115$ & $2651 \pm 618$ & $63,1 \pm 11,0$ & $73,7 \pm 3,4$ & $70,8 \pm 21,4^{*}$ \\
\hline & Cooked & $3080 \pm 435$ & $5425 \pm 351$ & $2266 \pm 311$ & $8,5 \pm 6,6$ & $77,4 \pm 4,8$ & $18,8 \pm 0,4$ \\
\hline \multirow[t]{2}{*}{ L. montanus } & Raw & $2074 \pm 750$ & $7690 \pm 458^{*}$ & $2443 \pm 802^{*}$ & $77,7 \pm 4,2$ & $73,3 \pm 5,9^{*}$ & $56,2 \pm 8,8^{*}$ \\
\hline & Cooked & $1278 \pm 423$ & $6332 \pm 152$ & $1402 \pm 70,2$ & $73,7 \pm 8,5$ & $59,9 \pm 4,1$ & $18,1 \pm 0,5$ \\
\hline \multirow[t]{2}{*}{ L. rotundiflorus } & Raw & $1887 \pm 503$ & $6166 \pm 115^{*}$ & $2213 \pm 471$ & $82,8 \pm 9,2^{*}$ & $79,0 \pm 6,3^{*}$ & $64,9 \pm 14,2^{*}$ \\
\hline & Cooked & $1316 \pm 472$ & $3771 \pm 556$ & $1652 \pm 638$ & $61,2 \pm 4,2$ & $62,9 \pm 1,2$ & $18,0 \pm 0,7$ \\
\hline
\end{tabular}

aMeans \pm standard deviation of three determinations.

Indicate significant differences $(p<0.05)$ for the same species in raw and cooked seeds. 
luteus (1500 mg/kg) [32], while the lowest value was found in L elegans (1777 $\mathrm{mg} / \mathrm{kg}$ ).

The $\mathrm{P}$ contents had the highest variation from $584 \mathrm{mg} /$ $\mathrm{kg}$ in L. exaltatus to $7690 \mathrm{mg} / \mathrm{kg}$ in L. montanus, superior to reported by Pablo-Pérez et al, [30] and with the exception of $L$. exaltatus, the rest of the analyzed species registered higher values of $P$ than $L$. luteus $(5100 \mathrm{mg} / \mathrm{kg}$ ), L. albus $(3600 \mathrm{mg} /$ $\mathrm{kg}$ ) and L. angustifolius (3000 $\mathrm{mg} / \mathrm{kg}$ ) [31]. In the remainder of the minerals contents were similar between species; L. elegans had the highest $M g$ register with $2656 \mathrm{mg} / \mathrm{kg}$, while L. rotundiflorus was the lowest with $2213 \mathrm{mg} / \mathrm{kg}$. These values are greater than those reported in domesticated species of $1400 \mathrm{mg} / \mathrm{kg}$ in L. albus at $2100 \mathrm{mg} / \mathrm{kg}$ in L. luteus. The range of Fe was of 61.8 to $82.8 \mathrm{mg} / \mathrm{kg}$, for L. exaltatus and $\mathrm{L}$. rotundiflorus respectively, whereas the $\mathrm{L}$. exaltatus seeds registered the highest values in $\mathrm{Zn}$ and Cu with 89,6 and 184 $\mathrm{mg} / \mathrm{kg}$ respectively, while in L. montanus the lowest levels of these elements were obtained with 73.3 and $56.2 \mathrm{mg} / \mathrm{kg}$ respectively. These contents were similar to those reported in domesticated lupines [31].

Overall, there was a loss in minerals by the thermal effect (table 2). The most affected was $C u$ which decreased $(p<0.05)$ in all species, mainly in L. elegans from 64.8 to $15.1 \mathrm{mg} / \mathrm{kg}$ (loss of $76.7 \%$ ), and the lowest was in L. exaltatus from 184 to $68.5 \mathrm{mg} / \mathrm{kg}$ (loss of $62.85 \%$ ).

In $\mathrm{P}$ had a significant loss in three species; the highest was L. elegans (6441 to $2876 \mathrm{mg} / \mathrm{kg}$, with a $55.34 \%$ of loss), L. rotundiflorus (from 6166 to $3771 \mathrm{mg} / \mathrm{kg}, 38.8 \%$ less) and lastly L. montanus (from 7690 to $6332 \mathrm{mg} / \mathrm{kg}$, with a loss of 17.66 $\%)$. Likewise, the Zn decreased significantly in three species, L. rotundiflorus, L. montanus and L. exaltatus, with losses of $20.38 \%$ (79 to $62.9 \mathrm{mg} / \mathrm{kg}$ ), $18.28 \%$ (73.3 to $59.9 \mathrm{mg} / \mathrm{kg}$ ) and $14.62 \%$ (89.6 to $76.5 \mathrm{mg} / \mathrm{kg})$, respectively.

The Fe (in L. elegans and L. rotundiflorus with a loss of $26.1 \%$ ) and $M g$ (in L. montanus and L. exaltatus with a loss of 42.6 y $27.43 \%$ respectively) only decreased statistically in two species. The mineral least affected was the Ca since statistically it only decreased in L. elegans from 1777 to $680 \mathrm{mg} / \mathrm{kg}$, with $61.56 \%$ loss, even though in the rest of the species there was also a reduction of this element, but it was not statistically significant $(p>0.05)$.

The most affected species was L. elegans since all their minerals were lost by cooking, for the reason that this species has the thinnest coat and when it was cooked it eliminated it faster, because according to Hung et al., [32] the minerals primarily concentrate on the endosperm of the seeds which caused a removal or leachate of minerals in the endosperm.

This occurs with legumes of popular consumption, with traditional cooking the minerals are lost, in beans the highest loss is of $\mathrm{P}(28.3 \%)$, in chickpeas is calcium with loss of $22.2 \%$ and in lentils the $M g$ (with 26\%) [33].

Additionally, Alajaji and El-Adawy [24], found that boiling in water causes losses in the content of $\mathrm{Ca}, \mathrm{Mg}, \mathrm{P}, \mathrm{Zn}, \mathrm{Cu}$ and $\mathrm{Fe}$, in chickpeas Seena et al., [22] reported that pressure cooking decreased the mineral content $(P, M g, F e)$ in a significant way in Canavalia cathartica seeds. On the contrary, Lazzari and Beleia, [34] reported that cooking does not affect the contents of calcium, zinc, and iron, in some varieties in soy seed.

\section{CONCLUSIÓN}

The results obtained allow to conclude that the thermal treatment used affects the content of nutrients in a different way depending on the lupin species. The rise in content of dietary fiber after cooking, suggests a potential consumption in these species without apparent toxicity risk with the favorable physiological advantages that provide this component.

The mineral content in raw seeds vary among species, L. elegans showed higher values of $\mathrm{P}$ and $\mathrm{Mg}$, in $\mathrm{L}$. exaltatus the highest levels of $\mathrm{Zn}$ and $\mathrm{Cu}$ were quantified while L. mexicanus and $\mathrm{L}$. rotundiflorus had the highest $\mathrm{Ca}$ and Fe contents, respectively. The analyzed lupins presented a higher level of $\mathrm{Ca}$ and $\mathrm{Mg}$ than the domesticated species of lupins. Overall, there was a reduction in minerals as a result of cooking; the most affected was the Cu which decreased in all of the species this may be due to lixiviation during the cooking process.

\section{RESUMEN}

El consumo de lupinos silvestres se limita por la presencia de alcaloides, sin embargo se pueden reducir con un tratamiento térmico adecuado. El objetivo de esta investigación fue determinar el efecto térmico sobre la composición química y de minerales de lupinos. En Lupinus mexicanus se observó una reducción en proteínas y grasas de 34,76 a 33,11 g/100 $\mathrm{g}$ y de 6,10 a 5,41 g/100 g respectivamente, un incremento de cenizas y fibra dietaria de 3,84 a 4,53 y de 20,9 a 28,48 g/100 g. La semilla cruda de L. mexicanus reveló el más alto contenido de $\mathrm{Ca}(3252,6 \mathrm{mg} / \mathrm{kg})$, Lupinus elegans en $\mathrm{Mg}$ con $2656,4 \mathrm{mg} / \mathrm{kg}$, mientras que Lupinus rotundiflorus fue de Fe $(82,8 \mathrm{mg} / \mathrm{kg})$ y Lupinus exaltatus en $\mathrm{Cu}(184,4 \mathrm{mg} / \mathrm{kg})$. Todas las especies mostraron similar contenido de $\mathrm{Zn}$ de 73,3 (L. montanus) to $89,6 \mathrm{mg} / \mathrm{kg}$ (L. exaltatus). En todas las especies disminuyó el $\mathrm{Cu}$, principalmente en L. elegans con una pérdida del 76,71\%.

Palabras clave: Lupinus, leguminosas, minerales, efecto térmico, fibra dietaria.

\section{BIBLIOGRAPHY}

1. Garcia, O., Infante R., Rivera C. Las leguminosas, una fuente importante de fibra alimentaria: Una vision en Venezuela. Rev Inst Nal Hig. "Rafael Rangel". 2009; 40 (1): 57-63.

2. Jimenez M. C., Mora E. R., Cardador M. A., Muzquiz, M., Martin P. M., Davila O. G. Effect of aqueous, acid, and alkaline thermal treatments on antinutritional factors content and protein quality in Lupinus campestris seed flour. Agric Food Chem. 2010; 58 (3):1741-5.

3. Mubarak, A. E. Nutritional composition and antinutritional factors of mung bean seeds (Phaseolus aureus) as affected by some home traditional processes. Food Chem. 2005; 89 (4): 489-95.

4. Trumbo, P., Schlicker S, Yates A., Poos M. Dietary reference intakes for energy, carbohydrate, fiber, fat, fatty acids, cholesterol, protein, and amino acids. J Am Diet Assoc. 2002; 102 (11): 1621-30.

5. Mendeloff, A.l. Dietary fibre and gastrointestinal diseases. Am J Clin Nutr. 1987; 45 (5): 1267-70.

6. Peters, U., Sinha R., Chatterjee N., Subar A. F., Ziegler R. G., Kulldorff M., Bresalier R., Weissfeld J. L., Flood A., Schatzkin A., Hayes R. B. Dietary fiber and colorectal adenoma in a colorectal cancer early detection programme. Lancet. 2003; 361 (3): 1491-5.

7. Brownawell, A. M., Caers W., Gibson G. R., Kendall C. W. C., Lewis K.D., Ringel Y., Slavin J. LPrebiotics and the health benefits of fiber: current regulatory status, future research, and goals. J Nutr. 2012; 142 (5): 962-74.

8. Rodríguez, R., Jiménez A., Fernández J., Guillén R., Heredia A. Dietary fibre from vegetable products as source of functional ingredients.Trens Food Sci Tech. 2006; 17(1): 3-15. 
9. Hodgson, J.M., Lee Y.P., Puddey I.B., Sipsas S., Ackland T.R., Beilin L.J., Belski R and Mori T.A. Effects of increasing dietary protein and fiber intake with lupin on body weight and composition and blood lipids in overweight men and women. Internat J Obes. 2010; 34 (6): 1086-94.

10. French, B., Shea G., Buirchell B. Introduction and history. In Peter, W., French B., McLarty A. (eds.) Producing lupins. Western Australia Government: Department of Agriculture and Food. 2008.

11. Sipsa, S. Lupin products-Concepts and reality. 12th International Lupin Conference. Canterbury (New Zeland). Proc Internat Lupin Assoc p. 506-13. 2008.

12. Ruiz., L. M. A., Garcia L. P. M, Castañeda V. H, Zamora N. J, Garzon de la Mora P, Bañuelos P.J. Chemical composition and antinutrient content of three lupinus species from Jalisco, Mexico. J Food Comp Anal. 2000; 13(3): 193-9.

13. Ruiz., L. M. A., Rodriguez M. R, Navarro P. S. Evaluacion quimico-nutricional de Lupinus exaltatus Zucc, del Nevado de Colima, Mexico, como fuente potencial de forraje. Interciencia. 2006; 31(10): 758-61.

14. Ruiz, M. A., Sotelo, A. Chemical composition, nutritive value, and toxicology evaluation of mexican wild lupins. $J$ Agric Food Chem. 2001; 49 (11): 5336-39.

15. Association of Official Analytical Chemists-AOAC Official Methods of Analysis 16th edn. 5rd. rev. Washington, D.C., The Association 1999.

16. Lagunes-Espinoza, L. C., López-Upton, J., García-López, E., Jasso-Mata, J., Delgado-Alvarado, A., García de los Santos, G. Diversidad morfológica y concentración de proteína de Lupinus spp. en la región centro-oriental del estado de Puebla, México. Acta Bot Mex. 2012; 99 (73): 73-90.

17. Guemes-Vera, N., Martinez-Herrera J., Hernandez-Chavez J.F., Yanez-Fernandez J., Totosaus. A. Comparison of Chemical Composition and Protein Digestibility, Carotenoids, Tannins and Alkaloids Content of Wild Lupinus Varieties Flour. Pak J Nutr. 2012; 11 (8): 676-82.

18. Wolko, B., Clements JC, Naganowska B. Nelson M.N., Yang H. Lupinus. Kole C ed. Wild Crop Relatives: Genomic and Breeding Resources. Legume Crops and Forages. Berlin, DE. Springer. p.153-206. 2011.

19. Muzquiz, M., Guillamon E., Burbano C., Pascual H., Cabellos B., Cuadrado C., Pedrosa, M. M. Chemical composition of a new Lupinus species found in Spain, Lupinus mariaejosephi H. Pascual (Fabaceae). Span J Agric Res. 2011; 9 (4): 1233-44.

20. Pastor-Cavada, E., Juan R, Pastor J.E, Alaniz M., Vioque, J. Analytical nutritional characteristics of seed proteins in six wild Lupinus species from Souther Spain. Food Chem. 2009; 117 (3): 466-9.

21. Rusníková, L., Straková E., Suchý P., Vopálenský J. Comparison of crude protein content and protein quality in lupin seeds. Lupin crops an opportunity for today, a promise for the future 13th International Lupin Conference, Poznań, Poland. Canterbury, (New Zealand). 2011. Proceeding of the International Lupin Association. 208-210. 2011.

22. Seena, S., Sridhar K. R., Arun A. B., Young C. C. Effect of roasting and pressure-cooking on nutritional and protein quality of seeds of mangrove legume Canavalia cathartica from southwest coast of India. J Food Comp Anal. 2006; 19 (4): 284-93.

23. Meiners, C. R, Derise N. L., Lau, H. C., Ritchey, S. J., Murphy, E. W. Proximate composition and yield of raw and cooked mature dry legumes. J Agric Food Chem. 1976: 24 (6): 1122-6.

24. Alajaji, S., and El-Adawy T. Nutritional composition of chickpea (Cicer arietinum L.) as affected by microwave cooking and traditional cooking methods. J Food Comp Anal. 2006. 19 (8); 806-12.

25. Písaříková, B., ZralýA, Z. Dietary Fibre Content in Lupine (Lupinus albus L.) and Soya (Glycine max L.) Seeds. Acta Vet Brno. 2010; 79 (2) 211-6.

26. Syed, M., Nasar-Abbas, Vijay J.. Effect of lupin flour incorporation on the physical and sensory properties of muffins. Qual Assur Saf Crop. 2012; 4, 41-9.

27. Pei-Yin Lin and Hsi-Mei Lai. Bioactive compounds in legumes and their germinated products. J Agric Food Chem. 2006; 54 (11): 3807-14.

28. Lintas, C., Cappelloni M., Montalbano S., Gambelli L. Dietary fibre in legumes: effect of processing. Eur J Clin Nutr. 1995; 49 (Suppl 3): 298-302.

29. Yagoub, A. E., Abdalla A. A. Effect of domestic processing methods on chemical composition, in vitro digestibility of protein and starch and functional properties of bambara groundnut (Voandzeia subterranea) seed. Res J Agric Biol Sci. 2007; 3 (1): 24-34.

30. Pablo-Pérez M., Lagunes-Espinoza L. del C., López-Upton J., Ramos-Juárez J. y Aranda-Ibáñez E. M. Morfometría, germinación y composición mineral de semillas de lupinus silvestres. Bioagro 2013 25, 101-8.

31. Gladstones, J. Composition and food uses of lupins. In Gladstones, J., Atkins, C., Hamblin J. (eds.) Lupins as crop plants, biology, production and utilization. Oxon, UK: Cab International, p 353-84. 1998).

32. Hung, T. V., Handson P. D., Amenta V. C., Kyle W. S. A., Yu R. S. T. Mineral composition and distribution in lupin seeds and in flour, spray dried powder and protein isolate produced from the seeds. J Sci Food Agric. 1988; 45 (2): 145-54.

33. Quinteros, A. Contenido de calcio, magnesio, hierro, cinc y fosforo en legumbres crudas y sometidas a distintos procesos de coccion. Rev Amaz Inves Alim. 2002; 2(1): 97-102.

34. Lazzari, K. E. N., Beleia, A. Effect of soaking and cooking on phytate concentration, minerals, and texture of foodtype soybeans. Ciencia Tecnol Alime. 2010; 30 , 1056-60. 